\title{
Analysis of professional training of future reserve officers in the system of modern military education
}

\author{
S. Smirnov \\ Eastern European National University named after Lesia Ukrainka, Lutsk, Ukraine \\ Corresponding author. E-mail: Dr.Servalio@meta.ua
}

Paper received 26.05.19; Accepted for publication 06.06.19.

https://doi.org/10.31174/SEND-HS2019-199VII33-12

\begin{abstract}
The main purpose of the concept of transformation of domestic military education is to achieve an effective system of training in accordance with the need for professional training and development of future military specialists in the conditions of full compatibility of national military education with the military educational environment of the Euro-Atlantic security space states. Ukrainian military education at the present stage is experiencing large and complex processes of reform. The length of these phenomena has been rather long in time due to their globalization. Reforms aimed at Euro-Atlantic integration should lead to a change in the format from the training of future reserve officers focused on career growth to the direction of the academic type of higher military education, in which the readiness of future military specialists will enable the need for professional conversion into military activities, and, vice versa.
\end{abstract}

Keywords: professional training, military education, reserve officer, military specialist, professional readiness, mentoring, leadership.

In the conditions of the modern militarization of the system of international relations, the intensification of military preparations, the increase of military budgets, the reformation and rearmament of the Armed Forces and other security structures of most countries, the issue of personnel readiness for combat missions becomes of particular importance.

The relevance of the study of innovation issues in military education is due to the need to seek ways to improve the quality of training of future reserve officers, due to the exhaustion of opportunities traditional approaches and technologies that take place in the military-educational process and taking into account the experience of combat operations in the east of Ukraine, experience Leading NATO countries for conducting modern armed struggle [18, p.202].

An integral part of higher education in Ukraine is the training of officers who are involved in the training of citizens in the reserve officers training program. In a situation where the system of higher education is fundamentally reformed in Ukraine, a number of military training units of higher education institutions have been reduced, there is a need for developing innovative approaches to designing the content of reserve officers training in military departments, which becomes of paramount importance and directly concerns the national security of the country, since they activity can significantly affect the combat readiness of military units and units. Consequently, there is a need for a qualitative development, implementation, continuous improvement (in accordance with modern requirements) of certain pedagogical foundations of the above-mentioned vocational training in higher educational institutions [14, p.128].

$\mathrm{S}$. Yaremchuk notes that the need to combine managerial functions with the transfer of professional knowledge, skills and skills to others (for example, personnel) necessarily leads to an increase in motivation to teach, including - an interest in educational and cognitive activity [23].

The implementation of the principles envisaged by the " Concept of the Development of the Security and Defense Sector of Ukraine» for the development of the security and defense sector will enable the creation of capable, multifunctional, mobile, well-trained, well-equipped, professional security and defense forces capable of effectively executing mission assignments [9].

E. Brigaty says that the professional training of future reserve officers should be aimed at forming a positive attitude to the profession, motivational adjustment, personality quality, procedural orientation of the person to a certain activity, moral and volitional personality traits, character traits, ability to learn, behaviors, practical skills and abilities, internal personality formations, professionally important cognitive processes, manifestations of temperament, internal settings and personal adaptations to successful action [8].

According to I. Tunik, the peculiarity of the professional training of reserve officers is the existence of situations in which it is necessary to make the correct decision in the short term, and in conditions of partial or complete uncertainty, therefore the essential characteristic of the reserve officer is his ability to possess such a situation, which requires Military Specialist of Great Intellectual Voltage [19, c. 140].

V. Baryshnikov, O. Neymarok argues that one of the drawbacks of the current modern system of stockpile training is the lack of physical education of students during training at the military training department, because they are engaged in their main educational institutions. Therefore, the study and development of these issues is proposed to be included in the curriculum [6, p.159]. The authors note that physical training in the system of training US reserve officers is not the last place.

A. Bobnikhov notes that the future reserve officer as a specialist in a narrow profile, should have a high professional competence with developed creative thinking. This task can be solved only with the close relationship of the educational process and the knowledge gained from the main - civilian specialty received on the main faculty and additional knowledge received in military departments at civil universities [7, p.28].

In this context, one should outline O. Kustinsky, in which it is stated that at the present stage higher education establishments preparing future reserve officers need to make a transition from the school of memorization to the school of thought. The officer must be able to make opti- 
mal decisions in a situation of constant change and skillfully manage subordinate units [13, p.115].

Future reserve officer needs to learn the ability to make non-standard decisions, creatively approach to identify the best ways to overcome difficulties. The creative activity of the officer does not arise out of his desire, but due to the constantly existing need to navigate and act in a complex rapidly changing situation. The need for creativity appears when a person faces difficulties that need to be overcome, and there are no ready rules (solutions) for solving this problem [2].

N. Kalinuk notes that among the wide range of competencies that a future reserve officer must own, a professional communicative occupy a special place. This is due to the specifics of the officer's professional activities, as well as the requirements for his professional readiness. The reserve officer must have the strategy and tactics of a business conversation and public speaking, adhere to the norms of ethics, psychology and communication culture, know and be able to apply in practice the communicative methods and techniques of managerial influence. In addition, in resolving the tasks of operational activities, the future officer must be able to communicate with both subordinates and with the local population in Ukraine and abroad [12, p.103].

The training of future reserve officers in higher education institutions should ensure the acquisition of the following knowledge and skills that will characterize the high level of formation: a clear understanding of the signs of future professional activity, high readiness for professional self-realization, the ability to express opinions and argue its advocacy, availability to analysis, synthesis and ability to establish causal relationships, criticality and self-criticism, social plasticity through tolerance, leadership and leadership Indian qualities [5, p.17].

Indicative in this respect, according to I. Tunik, is the presence of situations when it is necessary to make the correct decision in the short term in conditions of partial or complete uncertainty, therefore the essential characteristic of the reserve officer is his ability to possess such a situation that requires a military specialist of a large of intellectual stress, since each assumption of error is complicated by the possibility of using its opponent, because of which its negative consequences are greatly increased [20, p.140].

Revision of the main provisions of the Military Doctrine of Ukraine, the large-scale rearmament of the Armed Forces of Ukraine caused by the temporary occupation by the Russian Federation of part of the territory of Ukraine, and the presence of armed conflict in the eastern regions of Ukraine - require an innovative rethinking and modernization of domestic military education. The emphasis is on theory and methodology of military leadership and competence-oriented mentoring.

The study of the theory and methodology of military leadership is an important condition for the formation of the general and pedagogical culture of future officers as military specialists of the highest qualification level, which will subsequently replenish the reserve of officers in various fields of professional activity of the Armed Forces of Ukraine and other military formations.

The proposed work program of normative discipline «Military Science and Leadership» is developed on the basis of the curriculum: «Military Science and Leadership» (Courses (MILS) Military Science and Leadership), the educational standard of the USA in the direction of training: «Military Sciences: Officer of the Reserve» (Military Science: Army (ROTC) Reserve Officer Training Course) at civilian higher education institutions, where the main focus is on the formation of three main qualities that are characteristic of modern professional military: competence, responsibility and loyalty his business.

The educational discipline «Military Science and Leadership» examines the section of the educational and vocational training program of the Military Training University in Ukraine: «Method of work with personnel» and aims at qualitative development of the initial components of readiness of future reserve officers for professional activities, namely: cognitive, motivational, personallyoriented, emotionally-volitional.

The curriculum includes two modules. The first content module «Basic Course» (Basic Course) reveals the methodological and theoretical foundations of fundamental concepts and leadership doctrines, the practice of its effective skills, which underlie the solution of problems; Army values, expected behavioral ethics and officer experience are analyzed; addressing personal challenges and competences that are critical to effective leadership and communication; Students / cadets learn how personal qualities of life skills, such as cultural understanding, goal setting, time management, stress management and comprehensive physical fitness associated with leadership, job responsibilities and military occupation, are revealed; discloses the use of active listening and feedback skills; An analysis of the factors influencing the effectiveness of leaders and groups is conducted.

The second module «Advanced Course» examines the history of the Ukrainian army from the ancient Slavic civilization to the present; the ethics of command microclimate is studied; the readiness for success is formed as a result of practical leadership responsibility for satisfying the subordinate spiritual needs; the principles and methods of written and oral communication are revealed; Studying the experience of national advanced successful leadership; an analysis of the duties and methods of counseling, the principles of subjective motivation and organizational changes; the practical application of the principles of leadership in difficult situations is studied on the basis of the practical reproduction of the proposed thematic simulations; the basics of leadership of the direct level and the tactics of the small unit at the platoon level are studied; purposeful complex physical training is carried out for compliance and superiority of the standards of physical training established by the Armed Forces of Ukraine.

Leadership model is designed to help students maximize their potential. The Ukrainian Armed Forces are waiting and nurturing character leaders, which are good examples for imitation, constantly showing examples of accomplished missions. The Military Science and Leadership Development Leadership Training Program is a preview of the current ongoing military appraisal system, a preliminary assessment of the effectiveness of future reserve officers as potential leaders of the military units of the Armed Forces of Ukraine. 
The US military literature defines the concept of «leader development» as a continuous and progressive process of becoming a leader, which fully embraces his studies, education and experience through his own prism of self-development (Army Doctrine (ADRP)) [4]; conscious, continuous, progressive, competent, professional character of the leader (Strategy for the Development of the Army Leader (ALDS)) [21]; Competent and confident manager capable of decisive action (Field Guide (FM)) [10].

Despite the subtle differences in these definitions, there is still a common constant. Leadership is the process of the word. The continuous process of development of the leader takes place in three spaces: operational (professional environment), established (formal environment), individual (own environment) [3].

V. Hrytsanyuk argues that mentors are usually more educated and experienced people who do not put themselves in a position of dominance over others, but the pupil receives support, patience, enthusiasm, inspiration for new achievements. The mentors give new ideas, thoughts, open up prospects, and most importantly - instill social values and norms, using which, the pupil can socialize and arrange his life [11, p.47].

O. Semenog examines mentoring as a micro pedagogy of a teacher-tutor and his open environment in which an experienced specialist represents and his own example helps to form samples of behavior models, personal stances, teaches to read and interpret cognitive contexts, translates examples of assimilation of cultural norms and values, transmits value systems in shaping the thinking style of the pet. Personal and professional development, self-development, self-realization of the individual depends on the personality of the teacher-tutor, who skillfully accompanies, directs, dynamizes the process of adaptation to the requirements of the profession, to selfknowledge and self-development of individuals as selfsufficient and successful in the national and global space. Multidimensionality and multidimensionality of mentoring are characterized by the intellectual-ethical system of values that determine professional activity based on the pedagogically adapted experience of cognitive activity, the culture of high spirituality and morality, special behavior and communication, high quality of work and responsibility for its results [17, p. 46].

For example, the US Army, as a state institution, recognizes the need for implementation and implementation of targeted mentoring programs that are crucial for the upbringing and professional development of future military leaders in today's changing, uncertain, complex and ambiguous international environment. Strategic Conclusions and Recommendations on the Establishment, Implementation, and Development of Military Mentorship Concepts Influencing the Army as a whole, its Culture, and the Army Training and Leadership Development Panel have been developed by the US Army in the field of military leadership development (ATLDP) on the education system in the process of training future officers, on the training of future military experts, on the systemic approach to training and the development of leadership institutions. In particular, in the famous military pamphlet (Pamfhlet 350-58), Immortal Heritage, Development Leadership for the US Army interprets: «The commander as a leader solves the problem, develops, controls, and conducts collective and individual exercises, including them in professional development programs, and also stands as an organizer, primary teacher, trainer, consultant, in special cases - mentor. Mentoring is more personalized and individualized than traditional education. Mentoring involves frank dialogue, advice, career development, care and support, dedication and help» [22].

Military training of citizens of Ukraine under the program of officers is carried out at the expense of funds received from individuals and legal entities as payment for services related to training. Military training under the reserve officers program is considered part of the educational-professional program and curriculum of the corresponding faculty of the higher educational institution, is scheduled and conducted by the «day of war» method once a week. The results of mastering the program of reserve officers are included in the appendix to the diploma of higher education as a separate content module (educational discipline) - «Military training» [16].

The new paradigm of higher military education leads to a different vision of the position of the future officer of the reserve as a source of target, content and procedural characteristics of training. According to L. Petrova, the indicated tendencies in the development of higher military education determine the urgent need for the development of a methodology and technology for the implementation of higher military education as a person-oriented educational process, organization of teaching assistance to the harmonious personal development of the individual during training. The new socio-cultural paradigm prompts the search for appropriate factors, both in the present and in the strategic perspective, in the implementation of the tendency of the priority of the personally human principles of life, the free and creative development of the personalities of future military specialists, and the formation of the intellectual and moral potential of society in them. Therefore, the person-creating function, creation of conditions for self-improvement of the personality of both the cadet and the teacher should be the determining factor in the whole system of higher military education in Ukraine [15].

The main result of the professional training of future reserve officers is not only the availability of graduates of basic knowledge in various fields of science, a high level of professional skills, but also a certain readiness to be a competitor and to carry out defense and defense activities. We believe that in the process of studying at a higher educational institution, future reserve officers must master the values of military science at a level that would provide an optimal level of readiness for the fulfillment of tasks related to life-threatening.

Proposed pedagogical conditions of vocational training aimed at the formation and development of key competences for future reserve officers can be implemented qualitatively both in the context of the didactic unity of the academic theory of a higher educational institution and the process of real practical activity. The intensity of communication may vary depending on the type of professional activity. This didactic principle is also a prerequisite for the development of the ability to continuously adapt in the conditions of continuous scientific, technical, 
technological, economic, defense and security develop-

ment.

\section{REFERENCES}

1. A review of the official opponent for Volodymyr Valerievich Fedorenko's dissertation «Military-legal education of servicemen of the Armed Forces of Ukraine: socio-philosophical analysis», submitted for the degree of the candidate of philosophical sciences in the specialty 09.00 .03 - social philosophy and philosophy of history, Available at: http://eprints.zu.edu.ua/22200/1/vidguk_Mandragelya.pdf [Accessed 06 February 2019].

2. A.O. Kosobutsky, N.M. Filimontsev. (2011). Pedagogical conditions of training cadets of military high schools to overcome difficulties in their professional activities. Pedagogy. No.1 (49), P. 198-201.

3. Army Doctrine Reference Publication (ADRP) 10, Washington, DC: U.S. Government Printing Office, 2012.

4. Army Doctrine Reference Publication (ADRP) 7-0, Training Units and Developing Leaders. Washington, DC: U.S. Government Printing Office, 2012.

5. Babisheva M. (2016). Criteria and indicators of the formation of professionally significant qualities of future ship officers. Current problems of higher professional education in Ukraine. Materials of the IV International Scientific and Practical Conference. Under the. edit E.V. Luzik, O.M. Akmaldinova. NAU. p.p.226.

6. Baryshnikov V.V., Neymyrok O.K. (2015). Ways to Improve the Preparation of Reserve Officers in Ukraine. Systems of Information Processing. No.8, P.158-161.

7. Bobnyov A. I. (2010). Some aspects of the training of reserve officers at military departments in civilian higher educational institutions. Vestnik of Kem SU. No.2 (42), P.28-31.

8. Brigaty Ye. (2016). Features of professional readiness of reserve officers to work in extreme conditions. Bulletin of the National Academy of the State Border Guard Service of Ukraine. Series: Pedagogy. Vo. 5, Available at: http://nbuv.gov.ua/UJRN/Vnadped_2016_5_5 [Accessed 06 February 2019].

9. Decree of the President of Ukraine. (4, 2016). On the decision of the Council of National Security and Defense of Ukraine. «On the Concept of the Development of the Security and Defense Sector of Ukraine». No. 92. Available at: https://www.president.gov.ua/documents/922016-19832 [Accessed 06 February 2019].

10. Field Manual (FM) 6-22, Leader Development (Washington, DC: U.S. Government Printing Office, 2015), 11.

11. Gritsanyuk V. V. (2016). Mentoring as a Form of Preparing Orphaned Children for Independent Life. Social Work in Ukraine: Theory and Practice. No.3-4, P.44-51.

12. Kalinyuk N. V. (2013). On the problem of formation and development of professional communicative competence of future officers-frontier guards. Bulletin of the National Academy of the State Border Guard Service of Ukraine. No.3.
13. Kustinsky O. V. (2012). Experimental verification of the model of special training of future reserve officers. Collection of scientific works of the Khmelnytsky Institute of Social Technologies of the University of Ukraine. No.5, P.115-120.

14. Morozov S. M. (2013). Pedagogical bases of professional training of reserve officers in higher educational institutions. Pedagogical Sciences. Collection of scientific works of the National Academy of State Border Guard Ukrainian Studies: Pedagogical and Psychological Sciences. No.1 (66), P.127137.

15. Petrova L.O. Morality as a Valuable Modus of Military Education. (2014). Collection of scientific works of Kharkiv University of Air Forces. No.4, P.157-159.

16. Resolution of the Cabinet of Ministers of Ukraine. (February $1,2012)$. Procedure for conducting military training of citizens of Ukraine under the program of reserve officers. No. 48 (as amended).

17. Semenog O. (2017). Mentoring in the science and education of adults. Scientific notes of the Kirovograd State Pedagogical University named after Volodymyr Vynnychenko. Ser. Pedagogical Sciences. Vo.152, P.46-51.

18. Telelym V. M. (2013). Training of military specialists in the context of modern forms and types of armed struggle. Collection of scientific works of the Military Institute [Kyiv National Taras Shevchenko University. No.42, pp. 198-210. Available at: http://zakon4.rada.gov.ua/laws/show/344/2013 [Accessed 06 February 2019].

19. Tunik I. Yu. (2013). Psychological Assistance to the Development of Critical Thinking in the Educational Process in Higher Military Educational Institutions. Scientific Papers of MAUP. Sir: Economics. Psychological sciences. No.2, P.139144.

20. Tunik I. Yu. (2013). Psychological Assistance to the Development of Critical Thinking in the Educational Process in Higher Military Educational Institutions. Scientific Papers of MAUP. Economics. Psychological sciences. No.2, P. 139144.

21. U.S. Army, Army Leader Development Strategy (ALDS) 2013 (Washington, DC: Department of the Army, 2013) 3, accessed May 2016.

22. U.S. Department of the Army. (13 October 1994). The Enduring Legacy, Leader Development for America's Army, Department of the Army Pamphlet 350-58 (Washington, D.C.: U.S. Department of the Army) 13-14.

23. Yaremchuk S. V. (1999). Formation of professional psychological orientation of the personality of the future teacher: diss. Candidate psychologist Sciences: 19.00.07, p.p.216. 